[研究ノート]

\author{
調理の習熟度効果とエコ・クッキング教育効果の違い \\ ならびに料理におけるおいしさの評価 \\ 三神彩子***・長尾慶子* \\ (*東京家政大学，**東京ガス株式会社)
}

\title{
Comparison of the effects of proficiency in conventional cooking and the effects of education in eco-cooking, and sensory evaluation of dishes prepared with each method
}

\author{
Ayako Mikami*,**, Keiko Nagao* \\ * Tokyo Kasei University, 1-18-1, Kaga, Itabashi-ku, Tokyo, 173-8602 \\ ** Tokyo Gas Co., Ltd., 3-7-13, Nishishinjuku, Shinjuku-ku, Tokyo, 160-0023 \\ * 173-8602 東京都板橋区加賀 1-18-1 \\ ** 160-0023 東京都新宿区西新宿 3-7-13
}

With the aim of introducing eco-cooking into home economics classes, we performed the following experiments:

1. In a first-year class, according to a recipe from a cooking textbook used in a junior high school home economics class, we prepared a dish and assessed gas and water usage, amount of food waste, and required tools to calculate the total cost of cooking and $\mathrm{CO}_{2}$ emissions using both conventional and eco-cooking methods. We then performed sensory evaluation of dishes prepared with each method.

2 . In a second-year class, a dish was prepared twice with conventional cooking methods and once with eco-cooking methods after receiving eco-cooking education. We then compared the effects achieved by becoming proficient in conventional cooking with those achieved through eco-cooking.

3 . We introduced both methods in teacher-training courses and conducted a survey on the viability of incorporating eco-cooking classes.

Results revealed that eco-cooking used $41 \%$ less gas, and $77 \%$ less water, in addition to producing $28 \%$ less food waste and $44 \%$ less $\mathrm{CO}_{2}$ at a $62 \%$ lower cost. The results from the sensory evaluation of the two cooking methods indicated that there were no marked differences in taste.

Interestingly, a noticeable reduction in gas, water, food waste, cooking tools, cost and $\mathrm{CO}_{2}$ emission was not achieved by becoming more proficient in conventional cooking though repetition of the method. Furthermore, the survey from the teachertraining courses showed a large number of positive comments.

The above findings corroborate the importance of eco-cooking education and the effect of sufficient one-time education.

\section{1. 緒言}

地球環境問題の深刻化および2011年 3 月11日に太平洋 三陸沖を震源とした東日本大震竾（東北地方太平洋沖地
震）の影響を受け，地球温暖化防止の観点からだけでな く, 暮らし全体の中での食材, 水およびエネルギー資源 の有効活用, ゴミの削減化が求められており, 環境に配 慮した食生活「エコロジークッキング（以降エコ・クッ 
キング ${ }^{1)}$ と略称)」の考え方がますます重要となってき ている。エコ・クッキングとは, 環境のことを考えなが ら,「買い物」「料理」「片付け」を行う食事づくり（食 生活）を意味する。

これまでに著者らは, 家庭科教職課程にある大学生を 対象に授業の中でエコ・クッキング教育を導入すること で，対象学生や献立の違いにかかわらず，ガスや水使用 量, 生ゴミ量および $\mathrm{CO}_{2}$ 排出量に大きな削減効果があ ることを確認してきた ${ }^{2-7)}$ っさらに，食生活における環 境保全の取り組みである「エコ・クッキング」の教育の 効果は高く，その効果が持続することを確認してきた ${ }^{2,3)}$

そこで次の段階として，実際の家庭科教育現場への工 コ・クッキング教育の導入を目指し，本報では中学校家 庭科調理実習献立を用いてエコ・クッキングの教育効果 を実証するとともに，今回初めての試みとして出来上 がった調理品が通常の調理法とエコ・クッキングとで同 じようにおいしくできあがっているかを調理品の総合的 なおいしさを官能評価により検証した。

なお，これまでの研究では通常法での調理を実施後， エコ・クッキング教育を行い, 再度同じ献立についてエ コ・クッキングの考え方を取り入れた実習を実施してき た。しかし，この場合に何らかの習熟度効果が影響して いる可能性が推察された。さらに，エコ・クッキングの 教育効果が高いからといって通常の学校教育現場では同 じ調理を 2 度体験させることはカリキュラム上困難であ る。以上の問題点を勘案して，教育を行わずに同じ調理 を 2 度行った場合の習熟度効果を確認すること, そして エコ・クッキング教育（座学のみ）実施後に調理を行っ た場合の教育効果を確認することを，ガス，水使用量お よび生ゴミ量の実測值から $\mathrm{CO}_{2}$ 排出量および使用料金 に換算する方法で比較検討することとした。 以下得られた知見について報告する。

\section{2．調査方法および内容}

中学校家庭科教科書 ${ }^{8,9)}$ に準拠した献立 2 種を選択し， 本学家庭科教職課程 3 年生を対象に次のように 2 段階に 分けて実験を実施した。最初の段階である 1 年目は, 同 じ献立についてエコ・クッキングのポイントを取り入れ た調理実習を行う方法が，通常の調理法と比べてどの程 度ガス，水，生ゴミ， $\mathrm{CO}_{2}$ 排出量の削減効果がみられる かを確認することにした。同時に，それぞれの方法で仕 上げた調理品について官能評価を実施した。これは，工 コ・クッキングが環境に配慮されたものであると同時に おいしく調理されていることを検証するために今回初め て取り入れた。

次の段階である 2 年目は，異なる対象者に 1 年目と同 じ献立実習をし，その習熟度効果とエコ・クッキングの 教育効果の違いを確認する比較実験を行った。

なお，本実験では教科書に掲載されている方法を通常 の調理法（以後通常法）とし, 環境への配慮や工夫を行
い実習する方法をエコ・クッキング法（以後エコ法）と した。調査対象者, 調査期間, 実習献立, 調査方法を以 下に示した。

\section{（1）調査対象者}

1 年目の実験は平成 21 年度東京家政大学栄養学科家庭 科教職課程必修科目「食教育の研究」履修の 3 年生 47 名 （4５名／班で10班）とし， 2 年目の実験は平成 22 年 度の同大学同科目履修の 3 年生（25名，3〜4名/班で 8 班）を実験対象者とした。年度によって履修生および その人数が異なるが, 各年とも 1 献立当たり $4 \sim 5$ 組の データがとれるように配慮した。

\section{（2）調査期間および実験場所}

調査期間は平成 21 年度 (平成21年 4 月〜平成 21 年 7 月), および平成 22 年度（平成 22 年 4 月〜平成 22 年 7 月）の 2 か年にわたって実施した。実験場所は東京家政大学調理 科学学生実験室 (室温 $25 \pm 2{ }^{\circ} \mathrm{C}$, 水温 $27 \pm 1{ }^{\circ} \mathrm{C}$ ) とした。

\section{（3）実習献立}

実際に学校の授業でよく活用されている献立 2 種を取 り上げた。献立 $\mathrm{A} は ，$ 鮭のムニエルを中心に，付け合わ せ 2 種（サヤインゲンのソテー，ニンジンのバター者） と野菜入りコンソメスープとした。献立 Bは, ミートス パゲッティとポテトサラダの組み合わせとした。実習献 立の材料および配膳写真を図 1 に示した。

\section{（4）調理器具および測定機器}

使用する調理器具および食器類は既報 ${ }^{2-7)}$ 同様に実験 室設置のものとし, 調理器具は常時使えるように調理台 横のワゴン上に準備し，使用した器具数を記録すること とした。

測定機器として，ガスコンロ 2 台（ガスビルトインコ ンロ C3W89RDTLTG 株式会社ハーマン製)，ならびに 積算流量計 (ガス・水・湯) 2 台（愛知時計電機株式会 社製）を使用した。

\section{( 5 ） $\mathrm{CO}_{2}$ 排出量の換算方法}

上記実験で実測したガスおよび水使用量や生ゴミ量は, 既報 $^{3)}$ 同様に以下の換算式を用いて $\mathrm{CO}_{2}$ 排出量 $(\mathrm{g})$ に 換算した。

(1) ガスに起因する $\mathrm{CO}_{2}$ 量 $(\mathrm{g})=$ ガス使用量 $(\mathrm{L}) \times 2.21$ $(\mathrm{g} / \mathrm{L})$ ：都市ガス（1 $\mathrm{m}^{3}$ 当たり）の排出係数 $2.21 \mathrm{~kg}$ $\left[\mathrm{CO}_{2} / \mathrm{m}^{3}\right]$ は，東京ガスの都市ガス $13 \mathrm{~A} の$ 代表組成 ${ }^{10)}$ に基づく。

(2) 水に起因する $\mathrm{CO}_{2}$ 量 $(\mathrm{g})=$ 水使用量 $(\mathrm{L}) \times 0.909(\mathrm{~g} /$ $\mathrm{L})$ : 水 $\left(1 \mathrm{~m}^{3}\right.$ 当たり) の排出係数 $0.909 \mathrm{~kg}\left[\mathrm{CO}_{2} / \mathrm{m}^{3}\right]$ は，鈴木の報告 ${ }^{11)}$ に基づく。

(3) 生ゴミに起因する $\mathrm{CO}_{2}$ 量 $(\mathrm{g})=$ 生ゴミ量 $(\mathrm{g}) \times 0.43$ $(\mathrm{g} / \mathrm{g})$ : 生ゴミ $\left(1 \mathrm{~kg}\right.$ 当たり)の排出係数 $0.43 \mathrm{~kg}\left[\mathrm{CO}_{2} /\right.$ 


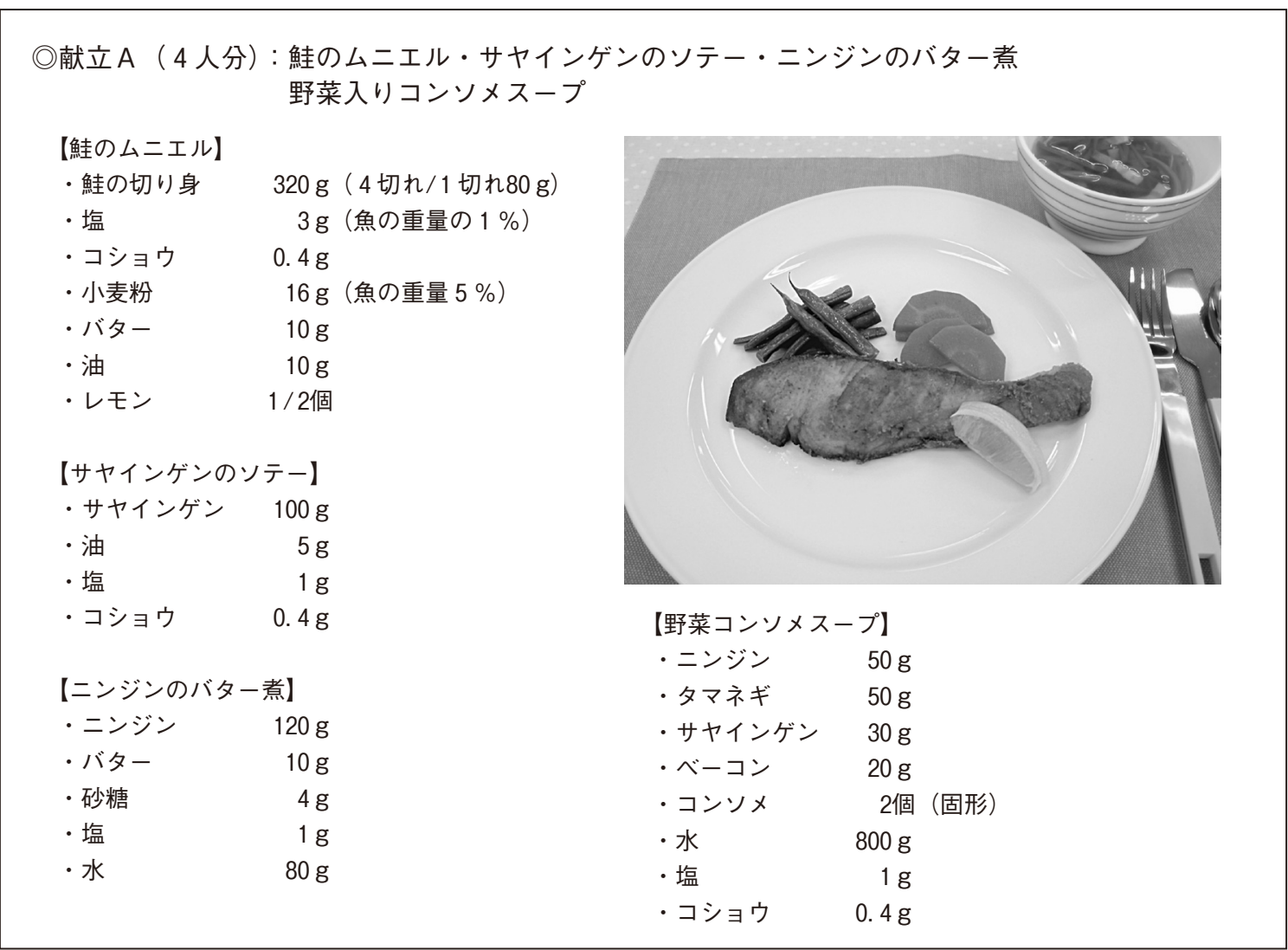

○献立B（４人分）：ミートスパゲッティ・ポテトサラダ

【ミートスパゲッティ】

・スパゲッティ $320 \mathrm{~g}$

・ひき肉 $200 \mathrm{~g}$

・ニンニク $5 \mathrm{~g}$

・タマネギ $200 \mathrm{~g}$

・ニンジン $40 \mathrm{~g}$

・油 $10 \mathrm{~g}$

・トマト水煮缶 $400 \mathrm{~g}$

- 水 $10 \mathrm{~g}$

・コンソメ 2個（固形）

・塩 $2 \mathrm{~g}$

・コショウ $0.4 \mathrm{~g}$

・粉チーズ $20 \mathrm{~g}$

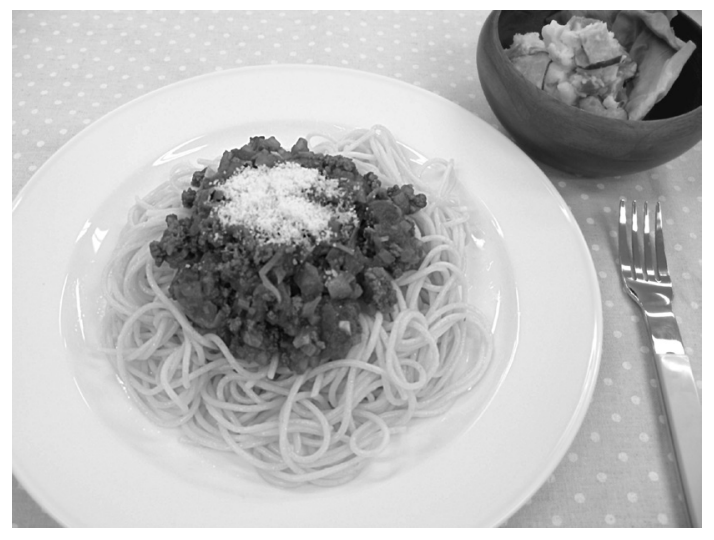

【ポテトサラダ】

・キュウリ $80 \mathrm{~g}$

・ジャガイモ $240 \mathrm{~g}$

・ニンジン $\quad 40 \mathrm{~g}$

・ハム $20 \mathrm{~g}$

・サラダ菜枚

・マヨネーズ $30 \mathrm{~g}$

・塩 $1 \mathrm{~g}$

•コショウ $\quad 0.4 \mathrm{~g}$

図 1 献立 A，Bの材料（分量）および盛り付け写真 
$\mathrm{kg}$ は，永田らの報告 ${ }^{12)} に$ 基づく。

\section{（6）使用料金の換算方法}

上記実験で計測されたガスおよび水使用量から，既 報 ${ }^{3)}$ に基づき，以下の料金換算式を用いて使用料金を算 出した。

(1) ガス料金 $($ 円 $)=$ ガス使用量 $(\mathrm{L}) \times 0.1168$ (円 $/ \mathrm{L})$

$1 \mathrm{~L}$ 当たりの料金 0.1168 円は, 東京ガス供給約款（東 京地区等 / 料金 $\mathrm{B} /$ 平成 21 年 10 月現在の原料費調整後 の単位料金）から引用した。
(2) 上下水道料金 $($ 円 $)=$ 水使用量 $(\mathrm{L}) \times 0.2483($ 円 $/ \mathrm{L})$ $1 \mathrm{~L}$ 当たりの料金 0.2483 円は, 東京都水道局上下水道 合計（平成21年度10月現在／東京都23区/メーター口径 $25 \mathrm{~mm} /$ 上水 $11 \sim 20 \mathrm{~m}^{3}$, 下水 $\left.9 \sim 20 \mathrm{~m}^{3}\right)$ から引用した。

\section{（7）エコ・クッキングの効果検証と官能評価}

既報 ${ }^{3)}$ に準じ，同一調理について通常法およびエコ法 での実習を実施し，ガス，水使用量打よび生ゴミ量を計 測し， $\mathrm{CO}_{2}$ 排出量ならびに使用料金を算出した。エコ法 で取り入れたエコポイント（表1）はエコ・クッキング

表 1 エコ法で取り入れたエコポイント

\begin{tabular}{|c|c|c|c|}
\hline \multirow{2}{*}{ 調理工程 } & \multicolumn{3}{|c|}{ エコポイント } \\
\hline & 献立 A · B 共通行動項目 & 献立 A & 献立 B \\
\hline 調理中 & 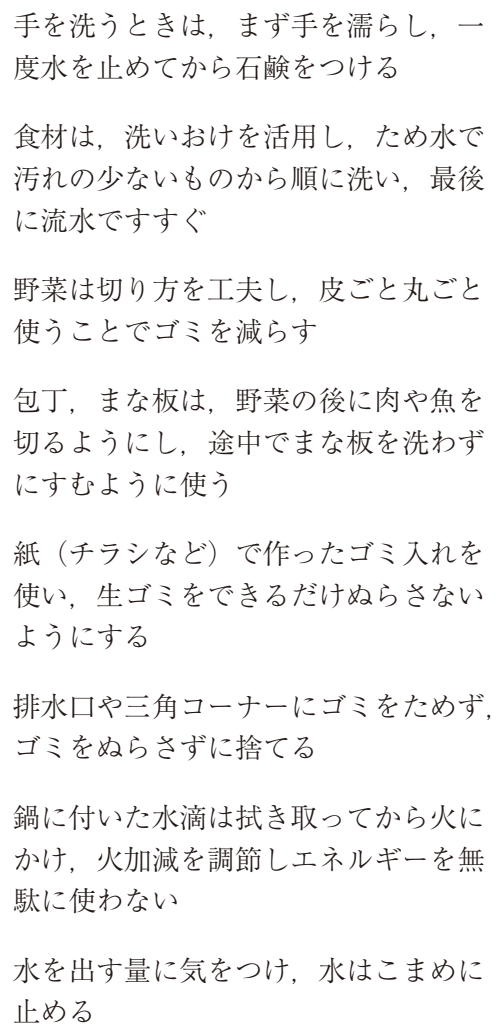 & $\begin{array}{l}\text { サヤインゲンの下茹では, 少量の水で } \\
\text { 蒸し茹でにすることで使う水とエネル } \\
\text { ギーを減らす } \\
\text { サヤインゲンのソテーを作ったフライ } \\
\text { パンで鮭のムニエルを作り, 洗い物を } \\
\text { 減らす } \\
\text { 鮭のムニエルは小麦粉を薄くむらなく } \\
\text { まぶし, 余分な粉を使わない } \\
\text { 鮭のムニエルは, バターと油をフライ } \\
\text { パンに入れてから火をつけエネルギー } \\
\text { を節約する } \\
\text { 鮭のムニエル, ニンジンのバター者は, } \\
\text { 蓋を活用し, 火加減を調整しエネル } \\
\text { ギーを節約する } \\
\text { 野菜コンソメスープは沸騰したら弱火 } \\
\text { にし, 蓋をして野菜が柔らかくなるま } \\
\text { で煮る }\end{array}$ & $\begin{array}{l}\text { 分量の水でトマト缶の中をすすぎ, } \\
\text { ミートソースの材料としてすべて使い } \\
\text { 切り, 缶を洗う水を節水する } \\
\text { ミートスパゲッティのソースを作ると } \\
\text { きは, 火加減に気をつけエネルギーを } \\
\text { 上手に使う } \\
\text { スパゲッティを茹でるときには, ポテ } \\
\text { トサラダ用の茹で野菜を同時調理する } \\
\text { 茹でる時の水量は } 3 \text { ～倍とし, 通常 } \\
\text { の } 5 \text { 10倍より少ない水量で水とエネ } \\
\text { ルギーを節約する } \\
\text { キュウリの塩もみは適量の塩で行い, } \\
\text { 水洗いせずそのまま使う }\end{array}$ \\
\hline 片付け & $\begin{array}{l}\text { 洗いおけにため水をし, 調理器具や食 } \\
\text { 器の下洗いに活用する } \\
\text { 使った食器は重ねない } \\
\text { 污れを古布やスクレーパーで拭き取っ } \\
\text { てから洗う } \\
\text { 水を出す量に気をつけ, 水はこまめに } \\
\text { 止める } \\
\text { 台布巾は } 4 つ \text { 折りにして面を上手に使 } \\
\text { い, 洗う回数を減らす } \\
\text { 水を出す量に気をつけ, 水はこまめに } \\
\text { 止める }\end{array}$ & & $\begin{array}{l}\text { スパゲッティの茹で汁は湯温があり, } \\
\text { 小麦粉の粒子が溶け出しているので, } \\
\text { 洗い物（下洗い）に使う }\end{array}$ \\
\hline
\end{tabular}


の授業で示した。さらに $\mathrm{A}, \mathrm{B}$ 献立の実習に使用した道 具や調理時の行動項目のチェックシートを記入した。

な扔，エコ法で作られた料理が通常法と同じ程度に拀 いしく仕上がっているかを検証するために，調理品の総 合的なおいしさについて 5 段階評点法による官能評価を 実施した。これは通常法を基準（０）とし，エコ法の調 理品について $-2 \sim+2$ の 5 段階で点数化する方法であ る。このようにしてエコ法での実習による教育効果を総 合的に検証した。

学生による実験終了後，本実験手法が学校現場で教育 プログラムとして実際に使用できるかどうかを確認する
ため, 教員研修（平成22年 8 月実施, 参加者34名）の場 で本献立でのエコ・クッキング実習をし，終了後に自由 記述方式によるアンケートを行った。

\section{（８）調理の習熟度効果とエコ・クッキング教育効果の 違いの検証方法}

図 2 に示した実験計画に基づき, 調理実習の経験を積 むことによる上達効果を検証するために，教科書に記載 されている通常法のレシピで1か月の間を抒き班ごとに 同じ献立を繰り返し実習させ，ガス，水使用量㧍よび生 ゴミ量を計測した。実習は，同一献立実習班 2 班ずつ実

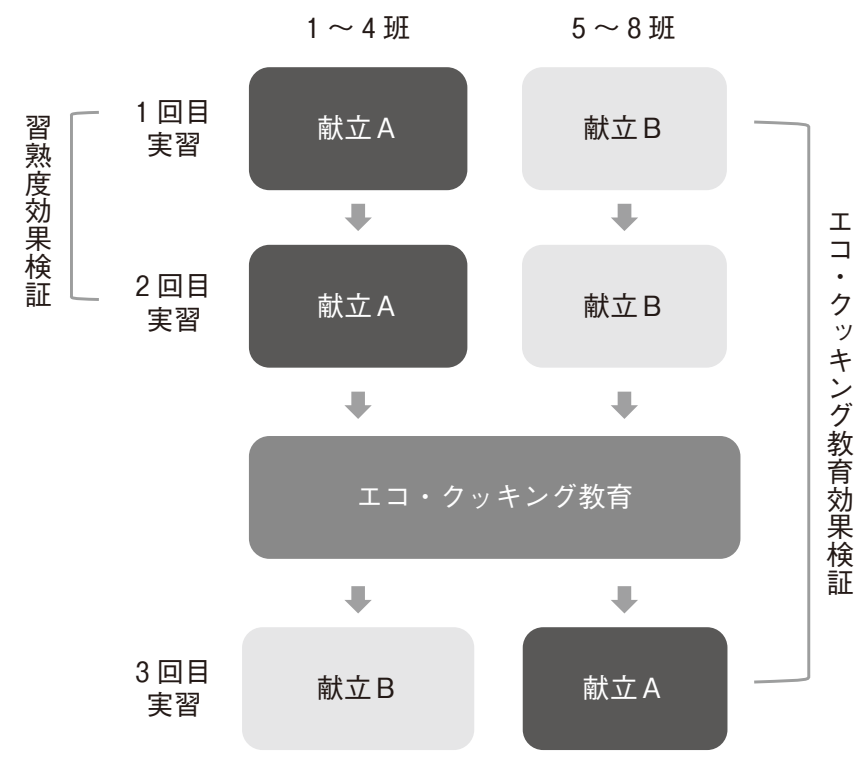

図 2 実験計画(調理の習熟度効果とエコ・クッキング教育効果の違い)

表 2 ガス, 水使用量, 生ゴミ量, 使用料金, $\mathrm{CO}_{2}$ 排出量の計測值と削減率

\begin{tabular}{|c|c|c|c|c|}
\hline & & $\begin{array}{l}\text { 通常法 } \\
(n=5)\end{array}$ & $\begin{array}{c}\text { エコ法 } \\
(n=5)\end{array}$ & 削減率（\%） \\
\hline \multirow{3}{*}{ ガス使用量 $(\mathrm{L}) \pm$ S.D. } & 献立A & $145.5 \pm 28.6$ & $85.8 \pm 5.5$ & 41.0 \\
\hline & 献立 B & $256.7 \pm 30.4$ & $153.4 \pm 5.6$ & 40.2 \\
\hline & 平均 & - & - & 40.5 \\
\hline \multirow{3}{*}{ 水使用量 $(\mathrm{L}) \pm$ S.D. } & 献立 A & $92.0 \pm 25.4$ & $22.9 \pm 8.4$ & 75.1 \\
\hline & 献立 B & $105.9 \pm 26.8$ & $23.2 \pm 4.9$ & 78.1 \\
\hline & 平均 & 99.0 & 23.1 & 76.7 \\
\hline \multirow{3}{*}{ 生ゴミ量 $(\mathrm{g}) \pm$ S.D. } & 献立A & $63.4 \pm 14.1$ & $44.4 \pm 28.6$ & 30.0 \\
\hline & 献立 B & $66.8 \pm 16.2$ & $49.0 \pm 13.6$ & 26.6 \\
\hline & 平均 & - & - & 28.3 \\
\hline \multirow{3}{*}{ 使用料金 $($ 円 $) \pm$ S.D. } & 献立A & $45.0 \pm 11.2$ & $16.7 \pm 3.3$ & 62.9 \\
\hline & 献立 B & $61.6 \pm 11.8$ & $24.2 \pm 2.2$ & 60.7 \\
\hline & 平均 & - & - & 61.5 \\
\hline \multirow{3}{*}{$\mathrm{CO}_{2}$ 排出量 $(\mathrm{g}) \pm$ S.D. } & 献立A & $413.7 \pm 86.3$ & $228.9 \pm 29.8$ & 44.7 \\
\hline & 献立 B & $678.0 \pm 92.2$ & $385.7 \pm 21.6$ & 43.1 \\
\hline & 平均 & - & - & 43.7 \\
\hline
\end{tabular}


験室にて実施した。次に，エコ・クッキングの教育効果 を検証するために，エコ・クッキングの教育を座学形式 で対象者全員に 1 回のみ実施した。内容は既報 ${ }^{3)}$ に準じ, 「エコ・クッキング」の考え方と食生活を取り巻く環境 問題についての講義（60分）とした。具体的には, 環境 問題の発生から現状, ならびに地球温暖化の仕組みとそ の取り組みを概説し，エコ・クッキングの目的と買い物， 料理, 片付けの各場面でのエコポイントを, パワーポイ ントを用いて具体的に解説した。あわせて今回の実習献 立に関するエコポイント（表1）を示した。

次にエコポイントを記載したレシピを配布し，これま で献立 $\mathrm{A}$ を 2 度実習している班は, 実習していない献立

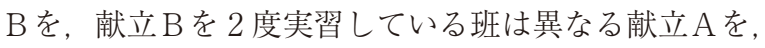
同条件で 2 班ずつ実習し，ガス，水使用量㧍よび生ゴミ 量の計測を行い, $\mathrm{CO}_{2}$ 排出量に換算し比較した。

\section{3. 結果と考察}

（1）エコ・クッキングの教育効果の検証と官能評価 1) ガス, 水使用量および生ゴミ量削減効果

ガス, 水使用量, 生ゴミ量, ガス・水使用料金, $\mathrm{CO}_{2}$ 排出量の結果を表 2 に示した。 A , B 献立間に差がある ものの, 削減効果（\%）は献立の違いにかかわらず同様 の傾向を示した。エコ法実施の場合，通常法に比べてA， B 平均削減率は, ガス使用量 $-40.5 \%$ (約 $82 \mathrm{~L}$ 減), 水 使用量 $-76.7 \%$ (約 $76 \mathrm{~L}$ 減), 生ゴミ量 $-28.3 \%$ (約 $18 \mathrm{~g}$ 減), 使用料金 $-61.5 \%$ (約33円減), $\mathrm{CO}_{2}$ 排出量 $-43.7 \%$ (約239g 減) となった。

\section{表 3 官能評価（5段階評点法）}

\begin{tabular}{c|l|c}
\hline \multicolumn{2}{l|}{} & $\begin{array}{c}\text { 通常法を基準 }(0) \text { と } \\
\text { した場合のエコ法の評 } \\
\text { 価 }(n=48)\end{array}$ \\
\hline \multirow{4}{*}{ 献立A } & 鮭のムニエル & $0.0 \pm 1.0$ \\
& インゲンのソテー & $-0.3 \pm 1.0$ \\
& ニンジンのバター煮 & $0.5 \pm 1.0$ \\
& 野菜入りコンソメスープ & $0.0 \pm 0.0$ \\
\hline \multirow{2}{*}{ 献立B } & ミートスパゲッティ & $-0.2 \pm 0.8$ \\
& ポテトサラダ & $-0.4 \pm 0.5$ \\
\hline
\end{tabular}

\section{2 ) 官能評価結果}

表 3 に示したとおり，通常法とエコ法によるそれぞれ の調理品の総合的なおいしさについて官能評価を行った ところ，いずれの献立でも大差がなく，有意差はみられ なかった。また, これまでも予備実験として本学研究室 研究員ら専門家 6 名による官能評価を行い，味だけでな く外観についても差がないことを確認している。このこ とからも製品の外観打よび拀いしさの評価は通常法と工 コ法のどちらに扔いても同程度で差がないと判断した。

3）教員研修アンケートの授業導入に関するコメント 本実験と同様のプログラムを教員研修で採用し, 終了 後に自由記述方式でアンケートを記述してもらった。主 なコメントを表 4 に示したが, 中学生でもできる内容で あるという評価や，経済問題，環境問題，エネルギー問 題など多方面から意識付けができるといった評価など, 実際の授業での導入に関し積極的な意見が多く見られた。

\section{（2）調理の習熟効果とエコ・クッキング教育効果の違 いの検証結果}

教科書記載の作り方で同じ献立を 2 度実習体験させた 場合のガス，水使用量および生ゴミ量の実測值を $\mathrm{CO}_{2}$ 排出量に換算した結果を図 3 に示した。

2 回目の実習時には, 手慣れた行動が実習中も観察さ れたものの, エコロジー的配慮ができるようになるかど うかといった観点からみると, ガス, 水使用量㧍よび生 ゴミ量の実測值から求めた $\mathrm{CO}_{2}$ 排出量は, $t$ 検定の結果 いずれも 1 回目と 2 回目では有意水準 $5 \%$ で有意差がみ られなかった。

一方，エコ・クッキングの教育後，はじめて実習する 献立（1，2 回目に献立 Aの班は献立 B を実施）で，工 コ法で調理を実施した結果を図 4 に示した。エコ・クッ キング教育後の実習では，いずれも顕著な削減効果が見

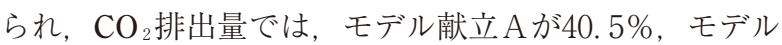
献立Bは52. 2\%（モデル献立A，B平均 $48.2 \%$ ）の削減 効果となった。

1 年目の実験と違う点は通常法とエコ法を同じ被験者 が行っていない点と調理実習の班の人数である。しかし， 表 2 の献立 A, B平均削減率 $43.7 \%$ と比較してみても教 育後の $\mathrm{CO}_{2}$ 排出量はいずれの献立に扔いても $40 \%$ 以上

\section{表 4 教員研修アンケートの授業導入に関するコメントの抜粋}

、調理は家庭科の授業の中でも生徒の関心が高く，一番理解させやすいと思う

授業の中でも簡単にすぐに取り入れられる

水，エネルギー，資源など，家庭科の教科の中でいろいろな場面で取り上げることが大切

、食生活分野の新しい取り組みだと思う

今回の実習は中学生でもできる内容である

、エコ・クッキングを指導することは経済問題, 環境問題, エネルギー問題と多方面から意識付けができる

、水やガス，ゴミの量など目に見えるもので学習をすると競争意識が出てより学習効果が深まる

、環境に意識を持たせるべくエコ・クッキングを体験させたい

、記憶に残る学習なので実習に少しずつでも取り入れていきたい 
$\square カ ゙ ス ~ \square$ 水 $\square$ 生ゴミ

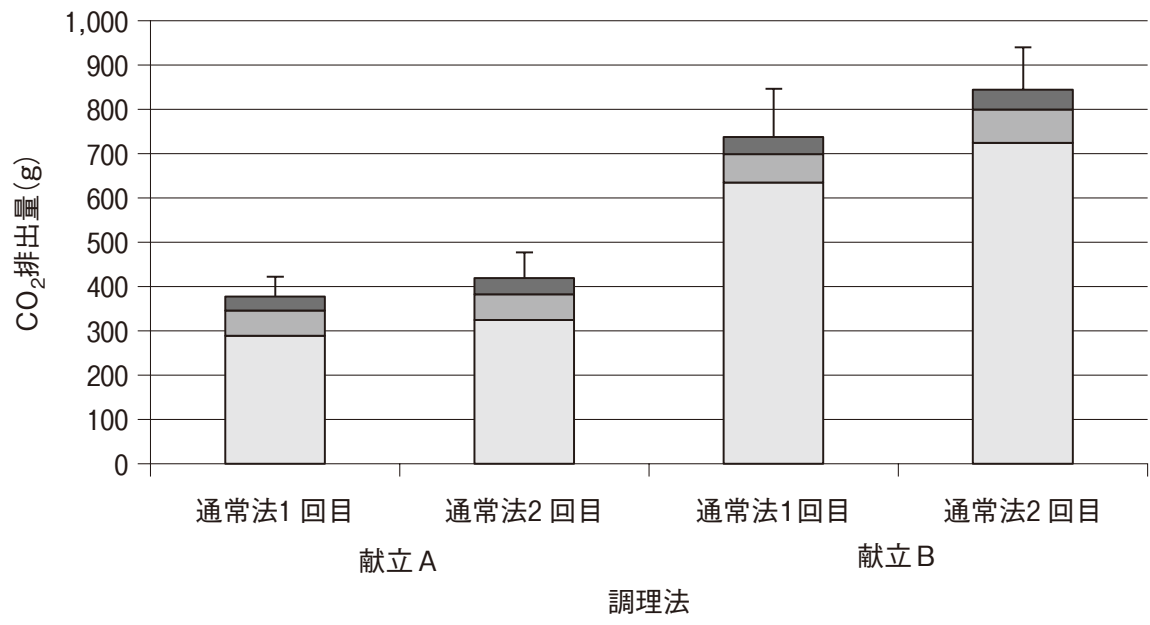

図 3 献立別の $\mathrm{CO}_{2}$ 排出量に及ぼす習熟度の影響

一通常法で同じ献立実習を 2 回くりかえした場合一

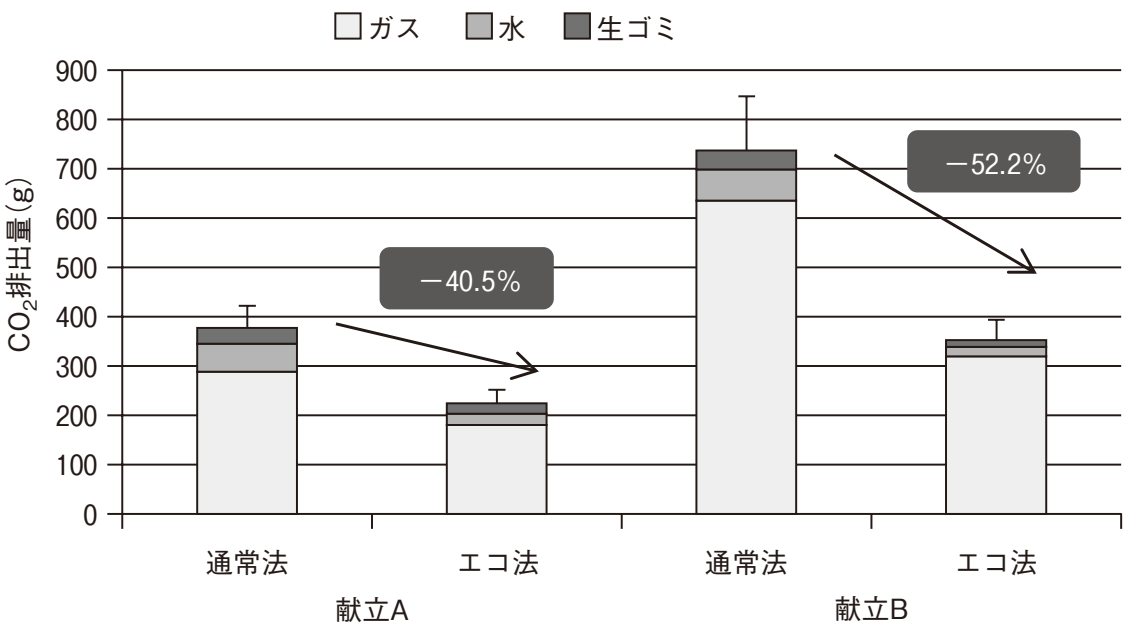

調理法

図 4 献立別の $\mathrm{CO}_{2}$ 排出量に及ぼすエコ・クッキング教育効果

一エコ・クッキング教育後に実習した場合の削減率（\%)一

の削減効果が得られており，エコ・クッキング教育後エ コロジーを意識して調理を行うことで，ガス，水使用量 および生ゴミ量の大幅な削減ができることが明らかと なった。

これまでに，教職課程の学生を対象に食教育の授業の 中で自らの実践を通してエコ・クッキングの効果を学ば せるため，エコ・クッキング教育前後で同じ調理を 2 度 体験させてきた ${ }^{2.3)}$ 。しかし実際の学校教育の現場にお いては，同じ調理を 2 度体験させることはカリキュラム 上困難である。しかし， $\mathrm{CO}_{2}$ 排出量の削減には，調理の 習熟度効果ではなくエコ・クッキングの教育効果が著し く高いことが今回の実験結果から明らかになった。既 報 ${ }^{2,3)}$ において教育効果が持続することが確認されてい ることから，環境に配慮した食生活を実践するために調 理実習を行う前にエコ・クッキング教育を行うことの重 要性が示唆された。

\section{4. 結論}

エコ・クッキング教育を実際の家庭科教育の現場に導 入することを目指し，中学校家庭科調理実習献立を用い て教科書に指示された方法とエコ・クッキングに留意し た方法とで比較を行った。また官能評価によるおいしさ の検証も行った。あわせて調理の習熟度による影響と事 前のエコ・クッキング教育による効果を検証した。得ら れた結果を以下に示す。

（1）エコ・クッキングの効果として，2 献立の平均で ガス使用量約 $41 \%$ ，水使用量約 $77 \%$ ，生ごみ量約 $28 \%$, 使用料金約 $62 \% ， \mathrm{CO}_{2}$ 排出量約 $44 \%$ といずれも高い削 減効果が得られた。あわせて出来上がった両調理法の 料理の, 総合的なおいしさについて官能評価を実施し たところ, 有意差はみられず同等の評価を得ているこ とが確認できた。 
（2）現場教員対象の教育研修に本献立でのエコ・クッ キング実習を取り入れアンケートをとったところ，エ コ・クッキング教育を授業へ活用することへの積極的 な意見が多くみられた。

（3）同じ調理を 2 度行うことで得られる習熟度効果と エコ・クッキング教育を行うことの教育効果を比較検 証したところ，習熟による環境に配慮した削減効果は 得られず，エコ・クッキングの顕著な教育効果とその 重要性が確認された。

以上より，中学校教科書に準拠した内容の調理実習の 中でエコ・クッキング教育を行う効果は大で，環境に配 慮した食生活を指導する上で 1 度の教育でも十分に教育 効果が得られることが示唆された。

\section{謝辞}

本研究の遂行に際しご協力いただいた，本学石谷（佐 藤) 久美さん, 松田麗子さんならびに東京ガスエコ・クッ キング事務局の伊藤貴英さん，布俣智美さん，アンケー トにご協力いただいた教員の皆様に深甚の謝意を表しま す。

\section{文献}

1）エコ・クッキング推進委員会：エコ・クッキング指導者 教本, エコ・クッキング推進委員会, 東京, pp. 7-8（2011）

2）長尾慶子，喜多記子，三神彩子：家庭科教職課程履修生 に対してのエコ・クッキングの教育効果，日本家庭科教育
学会誌, 50, 176-183 (2007)

3 ）三神彩子, 長尾慶子：家庭科教職課程履修生に対するエ コ・クッキング教育効果一野菜廃棄率, 使用器具数, $\mathrm{CO}_{2}$ 排出量, 消費エネルギー（費用）面からの詳細分析一, 日 本食生活学会誌，21，272-280（2010）

4) 長尾慶子, 喜多記子, 松田麗子, 加藤和子, 十河桜子, 三神彩子：家庭におけるエコ・クッキングの実践が $\mathrm{CO}_{2}$ 削 減に及ぼす効果，家政誌，59，903-910（2008）

5 ） 三神彩子，赤石記子，佐藤久美，長尾慶子：モデル調理 における調理工程ごとの水使用量の分析と節水行動による 効果，家政誌， 61，729-735（2010）

6 ) Ayako Mikami, Keiko Nagao : Positive Impact of EcoCooking on Environmental Load, ARAHE (アジア家政学会 誌), 18, 7-13 (2011)

7 ）三神彩子, 佐藤久美, 伊藤貴英, 村上和雄, 長尾：モデ ル献立調理時のエコ・クッキングによる排水污濁負荷削減 効果の分析, 日調科誌，44，367-374（2011）

8 ）東京書籍：新しい技術・家庭 家庭分野, 東京書籍, 東京, pp.48-65 (2005)

9 ）開隆堂：技術·家庭 家庭分野，開隆堂，東京，pp.4455 (2005)

10）東京ガス株式会社：ウルトラ省エネ BOOK，東京ガス株 式会社, p.30（2009）

11）鈴木敬子：無洗米，普通米の製造・利用におけるライフ サイクル $\mathrm{CO}_{2}$ 排出量, 日調科誌，42，342-348（2009）

12）永田勝也, 貝塚亮平, 押尾智英：廃棄物焼却発電システ ムの LCA 評価一新処理技術を組み合わせたゴミ処理の評価, 「第11回廃棄物学会研究発表会講演論文集」, pp.147-149 (2000) 